Banani is the author of The Modernization of Iran (1961) and editor and contributing author of The Epic of Kings (1967), Islam and Its Cultural Divergence (1971), Iran Faces the Seventies (1971) and Individualism and Conformity in Classical Islam, among numerous other publications.

He is survived by his wife Sheila Wolcott, daughters Susanne and Laila, and two grandchildren. $\&$

Editor

\title{
Suad Muhammad Gamal
}

1942-2013

IT IS WITH SADNESS WE ANNOUNCE THE PASSING OF SUAD MUHAMMAD GAMAL, on 19 May 2013. Suad served as Islamic Studies Librarian at Washington University in St. Louis from 1990 until her retirement in 2005. Responsible for reference, instruction, and collection development and management for Islamic and Near Eastern studies, she brought a wealth of knowledge, skills, and experience to Washington University. She was the library's first Islamic studies librarian and during her career at Washington University she took the initiative and did a remarkable job of building an impressive Islamic and Near East studies collection, including materials in Arabic, Persian, Turkish, and English. Suad was well respected and made enormous contributions not just to the library, but also to the intellectual life within the Islamic and Near Eastern studies community at Washington University, including providing bibliographic instructions at classes and serving as advisor to international student organizations. She was helpful, supportive, friendly, and cheerful, and devoted in her chosen profession. When travel became difficult she still managed to attend professional meetings and looked forward to being with her colleagues. Suad loved to share her deep faith and her love of Middle Eastern music and cooking.

Suad obtained her BA in Arabic Language and Literature from Cairo University in 1963, and her MA in Middle East History in 1981 and her MA in Library Sciences in 1984 from The University of Arizona. She worked in the Main Library of The University of Arizona for ten years before joining The Washington University Library in 1990. While serving on the library staff at The University of Arizona, due to her accumulated expertise, she trained newly 274 
appointed "professional" librarians in collection development, cataloging, and copy cataloging. Earlier, she spent two years in Berkeley, CA during her husband Dr. Adel Gamal's Visiting Professorship. There she took classes in English, which she had already started in 1977 when she was granted a scholarship to study in the Teaching Arabic as a Foreign Language Program at the American University in Cairo. She spent two summers at Portland State University (1972) and the University of Utah (1973). She also spent one academic year (19751976) in Tucson continuing her study in English and giving cooking lessons at a private non-profit organization.

Suad leaves behind her beloved family: husband Dr. Adel Gamal at The University of Arizona, daughters Randa Gamal and Sahar Gipson and their husbands, and her four adored grandchildren.

Tony Chang and Colleagues Washington University in St. Louis

and

Fayez Swailem

\section{Fawzi W. Khoury \\ 1938-2013}

FAWZI KHOURY BEGAN HIS CAREER IN THE UNITED STATES BY TEACHING ARABIC at Portland State University. In 1964, Fawzi was appointed head of the newly formed Near East Section of the University of Washington Libraries. Over a nearly thirty year period, Fawzi actively pursued acquisitions through vendors and many trips to the Middle East, was a national leader in the Middle East Librarians Association, mentored young librarians, published the Middle East in Microform, and was at the forefront of new initiatives in the field and in technology.

Among his regular biennial acquisition trips, during the 1977-1978 fiscal year, Fawzi made an acquisition trip to Tunisia, Cairo, Jordan, Tehran, and Baghdad. While in Iran, he was invited to visit Najaf and was gifted his choice of 110 titles from the Hijjat al-Islam, Muhammad al-Khu'i's library. In October of 1983, a time when acquisitions from North Africa were particularly difficult, Fawzi made a trip to Morocco, Tunisia, and Algeria. In the autumn of 1991, 